\title{
Factors That Influence Weight of Low Born Weight Baby (LBWB) in RSUD DR. H. MOCH. Ansari Saleh Banjarmasin
}

\author{
$1^{\text {st }}$ Ika Avrilina Haryono ${ }^{1}, 2^{\text {nd }}$ Anggrita Sari ${ }^{2}$ \\ $\left\{\right.$ ika.avrilina@yahoo.com $\left.{ }^{1}\right\}$ \\ Sari Mulia, University, $+628115669009^{1}$
}

\begin{abstract}
Low birth weight is one of risk factors which have contribution of new born death especially at perinatal phase. Number of low birth weight increase dur ing last 3 years at RSUD Dr. H. Moch. Ansari Saleh Banjarmasin at 2012 there is 174 case, at 2013 become 184 case and at 2014 increase to be 273 . The Purpose of this study was to analyze factors which affect the number of low birth weight. The research method of this research using analytical survey with case control ap proach. Population of this research are all maternity mother at VK RSUD Dr. H. Moch. Ansari Saleh Banjarmasin. Total number of sample case are 202 sample w ith total sampling technique and sample control 404 sample with systematic rand om sampling technique. Data collection with documentation maternal registratio $\mathrm{n}$ book technique. Data analysis done in bivariate with Chi Square test with $(\alpha=0$, 05 ) and Odds Ratio (OR). The result showed that there is an influence gestational age, paritas, gamelli, pregnancy complication with number of low birth weight. $F$ actors risk which very affect low birth weight is gamelli and of gestational age, $p$ regnancy complications, and paritas.
\end{abstract}

Keywords: Low Birth Weight, Gamelli, Pregnancy Complications, Paritas, and Gestational Age.

\section{INTRODUCTION}

Low Birth Weight Babies (LBWB) is one of the predictor mortalities which is very strong during the first few months of its life and the main cause of death, morbidities and deformities on a baby and children will also give a long term impact on health and adulthood. LBWB figures in Indonesia in 2010 were $11.1 \%$ and in 2013 they were 10.2\%. In South Kalimantan in 2010 the LBWB figure was $16.6 \%$. When compared with national figures based on these figures it is still quite high because LBWB is a problem if the prevalence is $>5 \% .^{1}$

One of the factors causing LBWB is gestational age, parity, twin pregnancy, and pregnancy complications where there is a significant relationship between gestational age, parity, twin pregnancy, and pregnancy complications with LBWB events. ${ }^{2}$ In babies with LBWB, there are 
many risk factors for problems with the body system, because the body condition is not yet stable, so perinatal mortality in LBWB is 8 times greater than normal babies. As a result, babies with LBWB can experience hypothermia due to the lack of fat in the body due to the regulation of body temperature in immature babies, respiratory problems, and can inhibit the growth and development of cognitive and chronic diseases in the Future. ${ }^{3}$

RSUD Dr. H. Moch. Ansari Saleh Banjarmasin is a type B public hospital in the city of Banjarmasin, South Kalimantan. Based on data obtained at Dr. H. Moch. Ansari Saleh Banjarmasin, infant cases with LBWB in 2012 there were 14 (8.2\%) of 2113 babies born, in 2013 as many as 184 (8.5\%) cases from 2167 total babies born and in 2014 increased to $273(10.2 \%)$ cases of 2666 total babies born. And in 2015 there were 202 LBWB cases out of 2784 total babies born. In addition, the number of infant deaths caused by LBWB has continued to increase over the past 3 years. In 2012 there were as many as 40 cases, in 2013 there was an increase to 44 cases and in 2014 It increased again to 54 cases. Based on the description above, it is up to the researcher to investigate the factors that influence the incidence of LBWB in RSUD Dr. H. Moch. Ansari Saleh Banjarmasin. Research purpose to analyze the factors that affects the incident at RSUD Dr. H. Moch. Ansari Saleh Banjarmasin.

\section{METHOD}

This research is an observational analytic survey research with case control design and using a retrospective approach. The population in this study were all women in the VK room of RSUD Dr. H. Moch. Ansari Saleh Banjarmasin from January to September 2015. This study used a group that is a case group is a mother who gave birth with LBW and a control group that is a mother giving birth to a baby with normal weight. The sample of this study is 1:2 in the case group totaling 202 taken in total sampling and the control group 404 taken in systematic random sampling.

The data collection method uses secondary data, namely the register book concerning data on maternity in RSUD Dr. H. Moch. Ansari Saleh Banjarmasin from January to September 2015 using a checklist. Analysis of the data used is univariate and bivariate analysis using the ChiSquare test.

\section{RESULTS AND DISCUSSION}

\subsection{Univariate Analysis}

Table 1. Frequency Distribution of Respondent Characteristic

\begin{tabular}{|c|c|c|c|c|c|c|c|}
\hline \multirow{3}{*}{ No } & \multirow{3}{*}{ Characteristic } & \multicolumn{4}{|c|}{ Group } & \multirow{3}{*}{$\mathrm{n}$} & \multirow{3}{*}{$\%$} \\
\hline & & \multicolumn{2}{|c|}{ Case } & \multicolumn{2}{|c|}{ Control } & & \\
\hline & & $\mathrm{f}$ & $\%$ & $\mathrm{f}$ & $\%$ & & \\
\hline 1 & Pregnancy Age & & & & & & \\
\hline & Preterm & 81 & 40,1 & 15 & 3,7 & 96 & 15,8 \\
\hline & Aterm & 117 & 57,9 & 376 & 93,1 & 493 & 81,4 \\
\hline & Post term & 4 & 2,0 & 13 & 3,2 & 17 & 2,8 \\
\hline
\end{tabular}




\begin{tabular}{|c|c|c|c|c|c|c|c|}
\hline \multirow[t]{4}{*}{2} & Paritas & & & & & & \\
\hline & First & 92 & 45,6 & 128 & 31,7 & 220 & 36,3 \\
\hline & $2-3$ & 75 & 37,1 & 208 & 51,5 & 283 & 46,7 \\
\hline & $>3$ & 35 & 17,3 & 68 & 16,8 & 103 & 17 \\
\hline \multirow[t]{3}{*}{3} & Twin Pregnancy & & & & & & \\
\hline & Yes & 29 & 14,4 & 1 & 0,2 & 30 & 5 \\
\hline & No & 173 & 85,6 & 403 & 99,8 & 576 & 95 \\
\hline \multirow[t]{3}{*}{4} & Pregnancy Compli & & & & & & \\
\hline & Complication & 122 & 60,4 & 96 & 23,8 & 218 & 36 \\
\hline & No Complication & 80 & 39,6 & 308 & 76,2 & 388 & 64 \\
\hline
\end{tabular}

Source: Primary Data 2015

\subsection{Bivariate Analysis}

Table 2. Bivariate Analysis Result

\begin{tabular}{|c|c|c|c|c|c|c|c|c|}
\hline \multirow{2}{*}{ Variable } & \multicolumn{2}{|c|}{ LBWB Case } & \multicolumn{2}{|c|}{ Kasus NBWB } & \multicolumn{2}{|c|}{ Total } & \multirow{2}{*}{$\begin{array}{c}\mathrm{P} \\
\text { Value }\end{array}$} & \multirow{2}{*}{ OR $(95 \% \mathrm{CI})$} \\
\hline & $\mathrm{f}$ & $\%$ & $\mathrm{f}$ & $\%$ & $f$ & $\%$ & & \\
\hline \multicolumn{9}{|l|}{ Pregnancy Age } \\
\hline Risk & 85 & 14,0 & 28 & 4,6 & 113 & 18,6 & \multirow{3}{*}{0.000} & \multirow{3}{*}{$\begin{array}{c}9,756 \\
(6,068-15,684)\end{array}$} \\
\hline No Risk & 117 & 19,3 & 376 & 62,1 & 493 & 81,4 & & \\
\hline Total & 202 & 33,3 & 404 & 66,7 & 606 & 100 & & \\
\hline \multicolumn{9}{|l|}{ Paritas } \\
\hline Risk & 127 & 21,0 & 196 & 32,3 & 323 & 53,3 & \multirow{3}{*}{0.001} & \multirow{3}{*}{$\begin{array}{c}1,797 \\
(1,272-2,539)\end{array}$} \\
\hline No Risk & 75 & 12,4 & 208 & 34,3 & 283 & 46,7 & & \\
\hline Total & 202 & 33,3 & 404 & 66,7 & 606 & 100 & & \\
\hline \multicolumn{9}{|l|}{ Twin Pregnancy } \\
\hline Yes & 29 & 4,8 & 1 & 0,2 & 30 & 5,0 & \multirow{3}{*}{0.000} & \multirow{3}{*}{$\begin{array}{c}67,555 \\
(9,130-499,874)\end{array}$} \\
\hline No & 173 & 28,5 & 403 & 66,5 & 576 & 95 & & \\
\hline Total & 202 & 33,3 & 404 & 66,7 & 606 & 100 & & \\
\hline \multicolumn{9}{|c|}{ Pregnancy Complication } \\
\hline Complication & 122 & 20,1 & 96 & 15,8 & 218 & 36,0 & \multirow{3}{*}{0.000} & \multirow{3}{*}{$\begin{array}{c}4,893 \\
(3,402-7,036)\end{array}$} \\
\hline No Complication & 80 & 13,2 & 308 & 50,8 & 388 & 64,0 & & \\
\hline Total & 202 & 33,3 & 404 & 66,7 & 606 & 100 & & \\
\hline
\end{tabular}




\section{DISCUSSION}

\subsection{Pregnancy Age}

Based on the frequency distribution table found that the incidence of LBWB (Low Birth Weight Babies) based on gestational age, most are at risk of gestational age (aterm) as many as 117 people (57.9\%) while gestational age based on NBWB (Normal Birth Weight Babies) also there are many at risk of gestational age (term) as many as 376 people (93.1\%).

Based on the results of the study the incidence of low birth weight obtained by the results of the chi square test $p$ value $=0,000<\alpha 0.005$, then $\mathrm{H} 0$ is rejected which means that gestational age affects the incidence of LBWB.

Normal newborns are babies born with a term gestational age (between 37 to 42 weeks) with a weight of 2500-4000 grams. Babies born at term are called full-term babies and these babies can also experience LBWB and can be born with normal birth weight (NBWB).

If LBWB events occur at term gestational age (37-42 weeks) where the baby's birth weight is less than 2500 grams, the baby is said to be a small baby during pregnancy (KMK). There are several factors that cause LBWB at term gestational age (37-42 weeks) including maternal factors that have a history of various complications such as hypertension and diabetes mellitus and pregnant women with anemia. In addition to maternal factors, there are uterine and placental factors that have complications such as disorders of umbilical cord inertia, placental deformities, and there is calcification in the placental area which causes the supply of food and oxygen to enter the fetus to decrease so that the baby experiences KMK, and fetal factors include in women with multiple pregnancy, there is an infection in the uterus, congenital defects, and chromosomal abnormalities. $^{5}$

Mothers who give birth with LBWB with term gestational age (full months) are influenced by good nutrition needed by a pregnant woman so that fetal growth does not experience obstacles, pregnant women do not have disease during pregnancy, and there are no health problems during pregnancy will give birth baby with NBWB. The gestational age at term with NBWB is an indication of the well-being of a newborn because the more adequate the gestational age the better the welfare of the baby (Sylviati, 2008).

Gestational age is an estimated fetal age that is calculated from the first day of the normal menstrual period to the time of delivery. The division of pregnancy according to WHO is divided into 3 groups namely Preterm ( $<37$ weeks / 259 days), Aterm (between 37 weeks to 42 weeks / 259-293 days), and Post Term ( $>42$ weeks / 294 days). 3

In general, infants less than a month / Post Term ( $<37$ weeks) are caused by several factors including the uterus being unable to hold the fetus, disruption during pregnancy, release of the placenta earlier than time or stimulation which facilitates uterine contractions before full months. Infants born less months have organs and organs that do not function normally to survive outside the uterus. The younger the gestational age, the organ functions are increasingly less perfect and the prognosis is increasingly poor.

These LBW groups often get complications or complications due to organ maturation due to lack of gestation (premature) so it is easy for infections and metabolic disorders to occur. Whereas in babies born more months (post term) caused by malnourished mothers (unable to eat green vegetables), anemia that continues during pregnancy so that post term babies experience growth and stunted development. 
At each stage of pregnancy, a pregnant woman needs food with different nutrient content and adjusted to body conditions and fetal development. In the first trimester, fetal growth is still slow, so the addition of nutrients needed is still relatively small. Entering the second trimester, the fetus begins to grow rapidly compared to before. The speed of growth reaches $10 \mathrm{gr}$ per day. Whereas in the last stage or third trimester, vitamins and minerals are needed to support the rapid growth of the fetus and brain formation. Fetal energy needs are obtained from the energy reserves stored by the mother during the previous stage. ${ }^{6}$

The results of this study are in accordance with the theory put forward which says that the baby's body weight increases according to the gestational age. The gestational age factor affects the incidence of LBWB because the younger the gestational age, the less complete growth of the fetus, both reproductive organs, respiration, and other organs so that it will also affect the birth weight of the baby. ${ }^{7}$

With the high risk of gestational age for LBWB events, it is recommended that pregnant women rest more, maintain their lifestyle, maintain their eating patterns during pregnancy and improve nutrition to prevent births with LBWB, and to health workers who check for pregnancy to emphasize each pregnant women to check their pregnancy regularly and according to the examination schedule so that if there are abnormalities will be detected immediately and will get immediate help.

Of the OR value of 9,756 which means that gestational age is a risk factor for LBWB events. Where gestational age (preterm and post term) has 9,756 times more risk to give birth to a LBW baby compared to mothers who have no-risk gestational age (aterm).

The results of this study are also in line with research who conducted research at the South Tangerang City Health Center, where the results of the study showed that mothers who gave birth to infants at risk of gestational age (preterm and post term) had 143.5 times the risk of giving birth to LBW babies compared to women who have a gestational age with no risk (term). ${ }^{8}$

\subsection{Parity}

Based on the table of frequency distribution of LBWB events based on parity there were many mothers who gave birth as many as 92 people $(45.6 \%)$ which was a risk category while LBWB events based on parity were mostly found at parity which were not at risk as many as 208 people $(51.5 \%)$.

Based on the results of LBWB events obtained by chi square test results obtained $\mathrm{p}$ value = 0.001 and $\alpha=0.05$ then $\mathrm{H} 0$ is rejected which means parity also affects LBW events.

LBWB events can occur in first-time mothers due to several factors including maternal age when pregnant less than 20 years because at a young age the development of reproductive organs and physiological functions are still not optimal because the age factor affects the condition of the cervix because it is too weak thus increasing the incidence of LBW with first maternal parity. ${ }^{9}$

The occurrence of LBWB is most likely to occur in mothers with parity who are not at risk (2-3 times have given birth) due to the age of many respondents at the safe age of 20-35 years so that the conditions and reproductive organs are mature (optimal) and most likely mothers who give birth 2-3 times giving birth to a baby with BBLN. The parity of 2-3 times is the safest parity in terms of maternal mortality compared to parity 1 and> 3 which have a higher maternal mortality rate. $^{10}$ 
Parity shows the number of children born to a mother. Parity is an important risk factor in determining the fate of the mother both during pregnancy and childbirth. Delivery is considered safe at the 2nd and 3rd delivery, while unsafe delivery is at the first and $>3$ deliveries. Pregnancy and first delivery increase the health risks that arise because the mother has never experienced a pregnancy before, other than that the new birth canal will be tried by fetus. Conversely mothers who give birth too often to the uterus will become weaker and there is a disruption of the placenta and blood circulation to the fetus so that the placenta does not get enough blood flow to deliver nutrients to the fetus as a result of impaired fetal growth. ${ }^{11}$

Mothers who have given birth for the first time and are still too young can affect their pregnancy, while mothers who have given birth $>3$ times are far more perfect reproductive organs than mothers who have just given birth (parity 1 ). Mothers who give birth repeatedly or give birth too often, affect the fetus they are carrying because there is disruption of the placenta and blood circulation to the fetus so that the placenta does not get enough blood flow to deliver nutrients to the fetus as a result of impaired fetal growth. Risks to parity 1 can be dealt with by providing information and counseling about factors affecting LBW and short-term and long-term impacts, while risks to high parity can be reduced and prevented by family planning.

Where the OR value of 1.797, which means parity is a risk factor for LBWB events. Where mothers with risk parity ( 1 and $>3$ ) have 1.797 times more risk to give birth to LBW babies compared to mothers with risk parity (2 and 3$)$.

The results of this study are also in line with research who conducted research on LBW in Lalan Subdistrict, Musi Banyu Asin District, where the results of the study found that there was a significant relationship between parity and LBW events where prim gravida mothers had a risk of 3.162 times greater compared to multigravida. ${ }^{12}$

\subsection{Twin Pregnancy}

Based on the table of frequency distribution of LBWB events based on the number of babies born there are many single fetuses as many as 173 people (85.6\%) while twin pregnancies based on LBWB are also common in single fetuses as many as 403 people $(99.8 \%)$.

Based on the results of the study the incidence of low birth weight obtained by the chi-square test results obtained $\mathrm{p}$ value $=0,000 \alpha=0.05$, then $\mathrm{p}<\alpha$, so $\mathrm{H} 0$ is rejected, meaning that there is an influence of multiple pregnancy with the incidence of Low Birth Weight.

LBWB events can also occur in a single fetus because the growth of a single fetus is determined by a number of genetic and environmental factors that are important around the uterus, namely placental perfusion, placental function that is very important for fetal growth. Mothers who have pregnancy complications such as anemia before pregnancy are also more likely to develop LBWB because the energy obtained by the fetus is used for growth, especially from glucose so that the potential for growth of a single fetus will be disrupted by genetic / chromosomal abnormalities, infection, and radiation. Environmental factors can also interfere with fetal growth, for example there is disease in the fetus, polyhydramnions and others. ${ }^{13}$

The occurrence of LBWB is likely to give birth to a single fetus because fetal body weight in twin pregnancies is lighter than fetuses in a single pregnancy with the same gestational age as 30 weeks' gestation. After gestational age > 30 weeks the weight gain of twin pregnancies is smaller due to excessive strain causing reduced placental blood circulation, therefore a single fetal body 
weight is most likely the mother gave birth to a normal birth weight (NBWB) and also the woman gave birth to NBWB because it is not there is a history of illness or pregnancy complications experienced by the mother now so that the baby is born with NBWB. ${ }^{14}$

In accordance with the theory put forward fetal growth in multiple gestational pregnancies depends on whether the placenta is single (mostly pregnant with monozygotic twins) or how to lucalise the implantation of the placenta. Considering these two factors, there may be a heart of one fetus that is stronger than the other, so that a fetus that has a weak heart gets less nutrients causing stunted growth. ${ }^{7}$

In twin pregnancies with excessive uterine cysts, preterm labor can occur. The need for mothers to grow twin pregnant is greater so that nutritional deficiencies such as pregnant women with anemia can interfere with the growth of the fetus in the womb. Food intake from mothers must be divided into 2 so that the twin fetuses get less food from the mother than a single fetus. Therefore, in dealing with multiple pregnancies, more intensive pregnancy surveillance is needed.

The existence of such an effect is stated, who states that fetal weight in twin pregnancies is lighter than fetal in single pregnancy at the same age. Up to 30 weeks of pregnancy the twin fetal weight gain is the same as the single pregnancy. Subsequently, the weight gain is reduced due to excessive stretching which causes the placenta blood to decrease. ${ }^{14}$

Where the OR value of 67.555 , which means twin pregnancy is a risk factor for LBWB events. Where mothers with multiple pregnancies have 67.555 times more risk to give birth to babies with LBW compared to mothers giving birth with a single fetus.

The results of this study are in line with research conducted at the Banda Aceh Mother and Child Hospital, where the results of the study found that there was a significant relationship between twin pregnancies with low birth weight babies (LBW) with a value of $\mathrm{P}=0.016$ and value of $\mathrm{OR}=3.028 .{ }^{15}$

\subsection{Pregnancy Complication}

Based on the table of frequency distribution of LBWB events based on pregnancy complications, there are many mothers who have pregnancy complications as many as 122 people $(60.4 \%)$ consisting of eclampsia, PEB/PER, oligohydramnios, anemia, breech location, antepartum hemorrhage, premature delivery, and hypertension gestational. While pregnancy complications based on NBWB are mostly found in mothers who do not have pregnancy complications as many as 308 people $(76.2 \%)$.

Based on the results of the study the incidence of low birth weight obtained by the chi square test results obtained $\mathrm{p}$ value $=0,000$ and $\alpha=0.05$ then $\mathrm{H} 0$ is rejected which means that pregnancy complications also affect the incidence of LBWB.

Pregnancy complications based on LBWB occurrences are very disturbing and hampering problems for the mother's well-being at the time of pregnancy such as bleeding, infection, parturition and the fetus can experience oligohydramnios, asphyxia, hypothermia, cyanosis, and so forth. So that causes mothers and babies born with various impacts and problems. From this study the most complications are found in the KPD where the amniotic membrane is not strong as a result of lack of connective tissue and vascularization, when cervical opening occurs the amniotic membrane is very weak and easily broken thereby increasing the risk of infection. Premature rupture of membranes is the biggest cause of preterm labor giving birth to LBWB babies, where 
the smaller the gestational age the greater the chance of infection in the uterus that can spur premature birth even with fetal body weight of less than 1000 grams. This is also in accordance with the opinion of Manuaba (2005) that pregnancy complications such as preeclampsia / eclampsia, antepartum hemorrhage, premature rupture of membranes and so on will affect LBWB births and are very life threatening to the mother and fetus.

Mothers who do not have pregnancy complications give birth to LBWB because there are no disturbances or problems during pregnancy, they often do ANC examinations so that babies are born with normal weight (NBWB). ${ }^{9}$

Pregnancy complications are one of the factors causing the birth of babies with LBWB from maternal factors. The complications of pregnancy include preeclampsia, KPD, eclampsia, gestational hypertension, anemia and other disorders, these conditions interfere with maternal health and also the growth of the fetus in the womb so that it increases the risk of birth of babies with LBWB. ${ }^{14}$

In this study pregnancy complications were mostly found in mothers with KPD, where. Premature rupture of membranes is a rupture of the membranes before delivery. When premature rupture of membranes occurs before 37 weeks' gestation is called premature rupture of membranes in premature pregnancy. The amniotic membrane ruptures due to an imbalance between extracellular synthesis and degradation of the matrix, changes in structure, cell counts, and collagen metabolism. One complication of premature rupture of membranes is increasing the risk of preterm labor and giving birth to a baby with LBWB. Premature rupture of membranes also causes oligohydramnios which will compress the umbilical cord resulting in asphyxia and hypoxia in the fetus and make nutrition to the fetus decrease and its growth is impaired.

Based on the research results of pregnancy complications that most influence LBWB are KPD, so mothers with KPD increase the risk of preterm labor and increase the risk of LBWB. For this reason, the role of midwives in conducting counseling on the importance of ANC examination and early detection of pregnancy and knowing pregnancy complications so that people understand and can make ANC visits so as to prevent LBWB.

Where the OR value of 4.893 , which means pregnancy complications are a risk factor for LBWB, where mothers with pregnancy complications have 4.893 times more risk for giving birth to LBW babies compared to mothers with no pregnancy complications.

The results of this study are in accordance with the theory at the BPRSU Rantauprapat which states that there is a significant relationship between LBWB and pregnancy complications. ${ }^{16}$

\section{CONCLUSION}

There was a significant effect of age at pregnancy and LBWB incidence with $\mathrm{p}$ value $=$ 0.000 , there was a correlation between parenting and incidence of LBWB with $p$ value $=0.001$, there was an effect of twin pregnancy and incidence of LBWB with $\mathrm{p}$ value $=0.000$, and there was a correlation between pregnancy complications with LBWB5 incidence $\mathrm{p}$ value $=0.000$. 


\section{REFERENCE}

[1] Riset Kesehatan Dasar. Badan Penelitian dan Pengembangan Kesehatan Kementrian Kesehatan RI: Jakarta (2010).

[2] Merzalia Nita. Determinan kejadian bblr di kabupaten belitung timur provinsi kepulauan bangka belitung. [Skripsi]. Depok: FKM UI (2012).

[3] Proverawati, Atikah, dan Cahyo Ismawati. Asuhan Pada BBLR, dan Pijat Bayi. Yogyakarta: Nuha Medika (2010).

[4] Manuaba, I.B.G, Ilmu Kebidanan, Penyakit Kandungan dan KB. EGC. Jakarta (1998).

[5] Albugis, Djamilah. Faktor-faktor yang mempengaruhi KEK pada ibu hamil di wilayah Puskesmas Jembatan Serong kecamatan Pancoran Mas depok Jawa Barat. Depok: Sarjana Kesehatan Masyarakat UI (2008).

[6] Manuaba, dkk. Ilmu Kebidanan, Penyakit Kandungan, dan KB untuk Pendidikan Bidan Edisi 2. Jakarta: EGC (2010).

[7] Sulistiani, Karlina. Faktor resiko kejadian bblr di puskesmas tangerang selatan. [Skripsi]. Tangerang: Universitas Islam Negeri Syarif Hidayatullah. (2012-2014).

[8] Rochjati, P., Skrining Antenatal Pada Ibu Hamil. Pusat Safe Mother Hood-Lab/SMF Obgyn RSU Dr. Sutomo/Fakultas Kedokteran UNAIR Surabaya. (2003)

[9] Prawirohardjo, Sarwono Ilmu kebidanan. Jakarta : Yayasan Bina Pustaka (2005).

[10] Depkes, RI. Kumpulan Buku Acuan Kesehatan Bayi Baru Lahir. Jakarta: Depkes RI (2004).

[11] Salmawati, Hubungan Antenatal Care Dengan Kejadian BBLR Tahun 2009-2010 di Kecamatan Lalan Kabupaten Musi Banyu Asin Sumatra Selatan. (Tesis). Depok: FKM UI (2011).

[12] Alwi, Hasan. Kamus Besar Bahasa Indonesia. Balai Pustaka: Jakarta (2007).

[13] Prawirohardjo, S. Ilmu Kebidanan. Jakarta: PT. Bina Pustaka (2008).

[14] Alya, Dian. Faktor-faktor yang berhubungan dengan BBLR di rumah sakit ibu dan anak banda aceh. , [Skripsi]. Banda Aceh: STIKES U'BudiyaH (2013).

[15] Simanjuntak, N.A. Hubungan Anemia Ibu Hamil dengan Kejadian Berat Bayi Lahir Rendah (BBLR) di Badan Pengelola Rumah Sakit Umum (BPRSU) Rantau Prapat Kabupaten Labuhan Batu. Skripsi. Universitas Sumatra Utara Medan (2009). 